EGU2020-12256

https://doi.org/10.5194/egusphere-egu2020-12256

EGU General Assembly 2020

(c) Author(s) 2020. This work is distributed under

the Creative Commons Attribution 4.0 License.

\title{
Plagioclase peridotite or olivine-plagioclase assemblage in orogenic peridotites: its implications on high-temperature decompression of the subcontinental lithosphere-asthenosphere boundary zone
}

\author{
Kazuhito Ozawa' ${ }^{1}$, Carlos Garrido ${ }^{2}$, Karoly Hidas ${ }^{3}$, Jean-Lois Bodinier ${ }^{4}$, Tomo Aoki ${ }^{1}$, and Françoise \\ Boudier $^{5}$ \\ ${ }^{1}$ Univeristy of Tokyo, Graduate School of Science, Earth and Planetary Science, Tokyo, Japan (ozawa@eps.s.u-tokyo.ac.jp) \\ ${ }^{2}$ Instituto Andaluz de Ciencias de la Tierra (IACT), CSIC - UGR, Armilla, Granada, Spain \\ ${ }^{3}$ Instituto Geológico y Minero de España (IGME), Tres Cantos, Madrid, Spain \\ ${ }^{4}$ Geosciences Montpellier, Montpellier, France \\ ${ }^{5}$ University of Montpellier, Faculté des Sciences de Montpellier, Place E. Bataillon, 34095 Montpellier, France
}

Orogenic peridotites are expected to provide direct information with high spatial resolution for a better understanding of the processes taking place in the lithosphere and asthenosphere boundary zones (LABZ), where the transfer mechanisms of heat, material, and momentum from the Earth's interior to the surface drastically change. Plagioclase peridotite or olivine-plagioclase assemblage sensu lato has been reported from some orogenic peridotites. The olivine-plagioclase assemblage in fertile systems is in principle not stable even at the depth of the upper most subcontinental lithospheric mantle (SCLM) because (1) the common crustal thickness in normal non-cratonic SCLM is $\sim 35 \mathrm{~km}$, (2) the Moho temperature for the mean steady-state continental geotherm is much lower than $600^{\circ} \mathrm{C}$, (3) the upper stability limit of plagioclase (plagioclase to spinel facies transition) becomes shallower with decrease in temperature, and (4) kinetic barrier for subsolidus reactions in the peridotite system becomes enormous at temperatures below $600^{\circ} \mathrm{C}$. The occurrence of olivine-plagioclase assemblage in some orogenic peridotite bodies, therefore, implies transient and dynamic high-temperature $\left(>800^{\circ} \mathrm{C}\right)$ processing at depth shallower than $20 \mathrm{~km}$ (plagioclase-spinel facies boundary at $\sim 800^{\circ} \mathrm{C}$ ), i.e., high-temperature decompression of LABZ up to the depth closer to the Moho. Adiabatic decompression of high-temperature LABZ leading to decompressional melting with inefficient melt segregation may give rise to plagioclase peridotite. Decompression along moderately high temperature adiabatic path or heating to allow subsolidus reactions leading to transformation of either spinel peridotites or garnet peridotites may give rise to plagioclase peridotite. However, decompression of LABZ associated with efficient cooling does not produce any olivine-plagioclase assemblage. Plagioclase peridotites thus could provide precious information on the dynamics of shallowing LABZ and underlying asthenosphere.

We have examined several orogenic peridotite complexes, Ronda, Pyrenees, Lanzo, and Horoman, to clarify the extent of shallow thermal processing based on olivine-plagioclase assemblage. The key approach of this study is searching olivine-plagioclase assemblage not only in various lithologies but also in microstructures, whose scale and mode of occurrence provide extent and 
strength of thermal processing in the shallow upper mantle. The wide-spread occurrence of plagioclase peridotites and localized partial melting in Lanzo suggest exhumation along high temperature adiabatic paths from the thermally structured LABZ in the Seiland subfacies; the predominance of plagioclase peridotites and its localized partial melting in Horoman suggest exhumation along variously heated paths from the garnet stability field; the moderate development of plagioclase peridotites without partial melting in Ronda suggest exhumation along variously but weekly heated paths from the spinel-garnet stability field, and the occurrence of minor plagioclase peridotites in Pyrenees suggests exhumation along cold path from the garnetspinel facies boundaries. We propose that the extent of shallower thermal processing decreases, and thus lithosphere thinning becomes less extensive in this order. 